\title{
Samantha Adams Festschrift: How to be a Student and How to Mentor Students-A Remembrance of Dr. Samantha Adams, Who Did These and Everything Else So Well
}

Catherine K. Craven ${ }^{1,2}$ Martha Adams ${ }^{3}$

${ }^{1}$ Clinical Informatics Group, IT Department, Mount Sinai Health System, New York, United States

2 Department of Population Health Science and Policy, Institute for Health Care Delivery Science, Icahn School of Medicine at Mount Sinai, New York, United States

${ }^{3}$ Division of General Internal Medicine, Department of Medicine, Duke University School of Medicine, Durham, North Carolina

Appl Clin Inform 2018;9:507-510.

At the time of her death, Samantha Adams, PhD, was an Associate Professor at Tilburg Institute for Law, Technology, and Society (TILT), at the Law School, Tilburg University, Tilburg, the Netherlands. The Tilburg University announcement that Sam had passed away on December 13,2017, offered a succinct description: Sam, who was reserved in professional settings, was warm and with good and positive humor in her interactions with others. In the earliest grief, these words seemed too little to capture all that we remember about Sam. In time, though, those simple words seemed to elevate themselves into the representative epitaph that they are. From the earliest days of Sam's first foray into American Medical Informatics Association (AMIA) at the 2000 Symposium as a $\mathrm{PhD}$ student, Sam displayed acumen for interactions in which she maintained professionalism while actively building warm friendships and collaborations. What follows are remembrances of Sam's time as a student in the AMIA Student Working Group, Sam's early student work, and how she carried forward the standout qualities demonstrated in those early days in interactions with her own students.

\section{Samantha Adams: A Standout Doctoral Student}

"I met Sam first at MEDINFO 2004, held in San Francisco, via the AMIA Student Working Group. What a standout she was: tall, statuesque, with a dignified energy, which was not diminished by her ability to break into hearty laughter and a wide grin after her favorite ice-breaker during introductions: 'Hi. I'm Sam Adams - like the beer!'” said Catherine K. Craven, PhD, MA, MLS. Sam had the gift of listening to others

Address for correspondence Catherine K. Craven, PhD, MLS, MA, Clinical Informatics Group, IT Department, Mount Sinai Health System, 150 E. 42nd Street 3rd Floor, New York, NY 10017, United States (e-mail: catherine.craven@gmail. com).

rather than speaking first, and she made whomever she was speaking to feel truly seen, heard, and appreciated. Never a thunder-or-scene-stealer at meetings, Sam was at the ready to volunteer when a call was made.

"At the time I joined AMIA in fall 2003, the AMIA Student Working Group was growing and building momentum. We were developing ambitious goals to create a set of operational guidelines, to gain more attention to the needs of students and trainees, particularly through a representative seat at the AMIA Board, and to develop a forum through which we could better communicate and network - while proving ourselves worthy of that coveted seat," Craven said. Today, the AMIA online communities and discussion lists are considerably more sophisticated, but at the time, the ability to have a discussion board with multiple threads was nonexistent. "Fair enough, we thought, we'll go old school."

"As such, we dedicated ourselves to creating a monthly newsletter 'The AMIA Student Working Group News,' linked as a PDF to the old AMIA website," said Craven. This meant there was a constant push for content from student volunteers who had many obligations. "As the inaugural Editor-in-Chief, I pushed hard during our MEDINFO 2004 meeting. What a relief it was when Sam volunteered to write a summary of ITHC 2004: To Err is System, IT in Health Care: Socio-technical Approaches, Second International Conference, which she was to attend immediately following MEDINFO 2004, September 13-14, 2004, in Portland, Oregon, USA." This was the first of several times Sam readily answered the desperate calls for content with a resounding and reassuring, "Yes, I can do that. How about...? Would that be okay?"

(c) 2018 Georg Thieme Verlag KG Stuttgart · New York
DOI https://doi.org/ 10.1055/s-0038-1666798. ISSN 1869-0327. 
"I can still remember a smile spreading on my face when I got the mid-September 2004 email from Sam with her piece on ITHC attached, and as always, right on time," said Craven. Like Sam herself, it was organized, thorough, apt, detailed, precise, and yet warm and evoking a sense of inclusion that clearly had been present at and central to the conference.

The piece starts out with Sam's introduction: "I take the liberty of beginning with a little background information. The Research group on IT in Health care practice and Management (RITHM) at the Erasmus University Rotterdam, The Netherlands, held the first conference on IT in Health Care (ITHC) in 2001. With the theme socio-technical approaches, we hoped, to begin with, to cover topics at the intersection of science and technology studies (known as social studies of science in the United States, I believe), medical informatics, CSCW and information systems research (at least!). We kept the conference short in duration and small in attendance in order to create a tight-knit 'workshop' environment that would allow for a thorough exchange of ideas. It was originally intended as a platform where students were especially encouraged to present their works in progress."1

Tight-knit, sociotechnical in focus, a thorough exchange of ideas, and especially helpful for students-this was pure Sam. What stands out all these years later is the level of sophistication in Sam's presentation of the conference session material while still a PhD student in her 20s.

Another time, shortly after, when Craven was seeking newsletter content, Sam again answered the call. Sam emailed with a joking but serious comment: "Is self-promotion okay? Because that is exactly what I would be doing!" This comment, followed by a smiley face, was so typical Sam. Sam's first-person introduction deftly and modestly acknowledged that it was easiest to write about what she knew best-her own dissertation work, on which she'd been working for 4.5 years. "You could count on her to say and do the right things," Craven said.

Sam's article detailed her dissertation research "entrenchment within the debate about whether or not medical information on the World Wide Web is reliable - and, with most authors having decided that it is not, what to do about that 'problem,' as it were." She explained her journey, starting in 2001, in which she began researching reliability work inside well-known organizations that were developing or had developed tools to help lay Internet users find reliable medical information on the Web. She conducted research at Health on the Net (HON) in Geneva focusing on their ethical code and seal, a searchable database, and later, a specialized browser, and at the Department of Health and Human Services (DHHS) in the United States focusing on the healthfinder Web portal. She also collected data from the Ministry of Health in the Netherlands, which launched a health portal in 2001, and from TNO, a Dutch research and development organization that developed a special portal and hyperlink seal for sites, as well as from the U.S. National Library of Medicine (the Medlineplus Web site), Dr. Stephen Barrett (Quackwatch), and Dr. Gunther Eysenbach (the MedCertain third-party reviewing structure plus a seal, and later, the MedCircle browser). After these visits to HON and DHHS, Sam initiated a second, complementary component, researching lay reliability judgments, an ethnographic study of Dutch patients' searching practices in an "as real as possible" search setting. ${ }^{2}$

Again, what stands out is the rigor of Sam's writing, her detailed scholarly approach, and her humane focus on the human factors, exactly what one would hope of a sociotechnical researcher, yet with evidence of sophistication beyond what is expected even in the brightest students.

\section{Dr. Samantha Adams' Students Pay Tribute: "It Is a Privilege to Help Honor Sam"}

Other contributions to this Festschrift delve into Sam's further development as a scholar as she moved beyond her student days. For the remainder here, however, we want to draw Sam forward from her student days to her approach with her own students, via their experiences. They, too, knew Sam as someone whose character never wavered: Sam was steadfast, dedicated to excellence, detailed, professional, yet always warm, and ready with self-deprecating humor.

Former PhD student at Erasmus University Femke Vennik, $\mathrm{PhD}$, first met Sam while pursuing a bachelor's degree in Health Sciences in 2009. Vennik took several courses that Sam taught, including one on qualitative methods.

"She was such a nice and fun teacher to listen to. Her way of presenting was so natural. Nothing rehearsed, right on time, and to the point," said Vennik. "She was also very down-toearth and had a great ability to make jokes (mostly of herself). Her Dutch with a beautiful American accent was excellent." When Vennik pursued a PhD program at Erasmus in 2010, with a research focus on patient participation on the World Wide Web, Sam became her doctoral mentor. Vennik remembers Sam as always there, always willing to help her find the right literature and to guide her in teaching. "Sam's knowledge of ICT in healthcare and her (English) writing skills helped forward my work tremendously. I cannot thank her enough for that." Vennik is particularly grateful for Sam's tip to write summaries of articles within the bibliographic software package Refworks to accompany the citations. "She said it is a time investment but so worth it. And she was right. Another great tip was the use of the 'cars' model by John Swales for writing paper introductions. It has helped me many times."

"Sam was also willing to share many other things with me such as the 'must-sees' in America," said Vennik (Email correspondence with Femke Vennik, February-March; 2018).

Bethany Hipple Walters, PhD, remembers her first interactions with Sam, who became her daily PhD supervisor and friend. "My first contact with Sam was in 2009. I was looking for a $\mathrm{PhD}$ position in health policy in the Netherlands, as I was moving to Europe from Boston. I'd actually applied to a different position and was passed on to Sam. In the first email to me, she offered not only information about the research but advice on moving from the US to the Netherlands." Hipple Walters began as Sam's PhD student in February 2010 on a project studying chronic disease programs.

"I had been a health services researcher for many years before my PhD. Despite my experience, my PhD was not without challenges, especially in more theoretical aspects," 
said Hipple Walters. "Sam guided me in this, showing me that there was often more to my data than met the eye and teaching me how to tie my data to larger theories and trends. It was a hard lesson but one that I remain thankful for." The two wrote many papers together. "She had a great-and sometimes painful-critical eye that strengthened my writing," said Hipple Walters, echoing all that we know about Sam's attention to detail and rigor. "Sam and I both had strong backgrounds in research methods and occasionally taught workshops on methods together. I think of her often when I teach research methods now, using the same examples that she used."

"We bonded over missing warm weather, as I grew up in Oklahoma, and she was raised in North Carolina," said Hipple Walters. The two talked also about missing American treats, and they smuggled peanut butter cups and American cold medication back from the United States for each other. "We drank lots of tea together and chatted about politics, books, and travel" (Email correspondence with Bethany Hipple Walters, February-March; 2018).

Marcello Aspria, MSc, is a former PhD student and colleague of Sam's at Erasmus University. He first met Sam in summer 2009, when he applied for a PhD position at the Erasmus School of Health Policy and Management, where Sam was an Assistant Professor in the Department of Health Care Governance. She became Aspria's doctoral supervisor in a research project on health portals.

"Although we had different academic backgrounds, we had a shared interest in critical and feminist theories," said Aspria. "She introduced me to the world of medical informatics, actor-network theory, and her favourite authors in science and technology studies. I learned so much from her."

"Having Sam as a supervisor meant being in good hands. She knew how to guide me in a world that was new to me; at the same time, she gave me space to discover things on my own," said Aspria. He remembers Sam as rigorous and meticulous in her own work, with a sharp eye for detail, but also as someone who appreciated creativity. Throughout Sam's appointment in Rotterdam, they continued to do research and teach classes together, coauthor papers, and explore different ways to structure his dissertation. They kept in touch after Sam moved to Tilburg University, where she invited Aspria to participate in a seminar at her new department. Aspria, too, remembers Sam as well-rounded.

"Sam was an academic through and through; a specialist in her field, but with a curious disposition and a healthy interest in life outside academia," he said. "For instance, you could always talk to her about her favourite soccer club, PSV Eindhoven. She was a real fan!"

"Sam's legacy now rests in all the written work she has left behind," said Aspria. "I feel honoured to have made a very modest contribution to that work, but deeply saddened that it ended so quickly" (Email correspondence with Marcello Aspria, February-March; 2018).

Anna Berti Suman is a PhD researcher at the TILT, Tilburg University, Tilburg, the Netherlands. She first came to know Sam well before coming to Tilburg University to start her PhD program there with Sam as her doctoral supervisor. At the time, Berti Suman was an environmental lawyer and researcher in Ecuador.

"Since the time of our long 'inter-continental' email exchanges, Sam showed me commitment and dedication in guiding me towards the beginning of my PhD," said Berti Suman. "I remember the readings she shared with me to help me understand TILT's perspective on my Health \& Technology PhD track, tirelessly adding her personal point of view and a word of encouragement." When Berti Suman started her PhD program, Sam was already on maternity leave with her daughter, Jadzia Berden. "Nonetheless, she welcomed me in her house to meet each other in person. I was immediately amazed by Sam's personality: resolute, passionate and energetic, always down to earth, open to discussion. That day, I went home with a rucksack full of books lent by Sam and, most importantly, the heart full of Sam's kindness and enthusiasm," remembered Berti Suman.

When Sam returned to the office, they worked together on the organization of TILTing Perspective 2017, the Institute's biannual conference, for the Health Care Track.

"From those busy times, I treasure a memory of Sam and me walking in the university forest to reach the venue of the conference keynote dinner. We got lost, when I was supposed to be the one to know the route. Sam just laughed about it, and we enjoyed that time of forest wandering as an occasion to chat more," said Berti Suman. The two often engaged in conversation going way beyond Berti Suman's PhD project or their shared academic activities. "We talked for hours in front of a coffee about our families, our lives of 'expats,' about gender imbalances, and other challenges in academia."

Sam appreciated Berti Suman's curiosity for the sociological world and for qualitative methods, and Sam always believed that a scholar trained as "purely" legal, as Berti Suman was, could dare to embrace empirical methods, and guided Berti Suman through these. Berti Suman remembers her first interview, how worried she was, and how wisely Sam advised her.

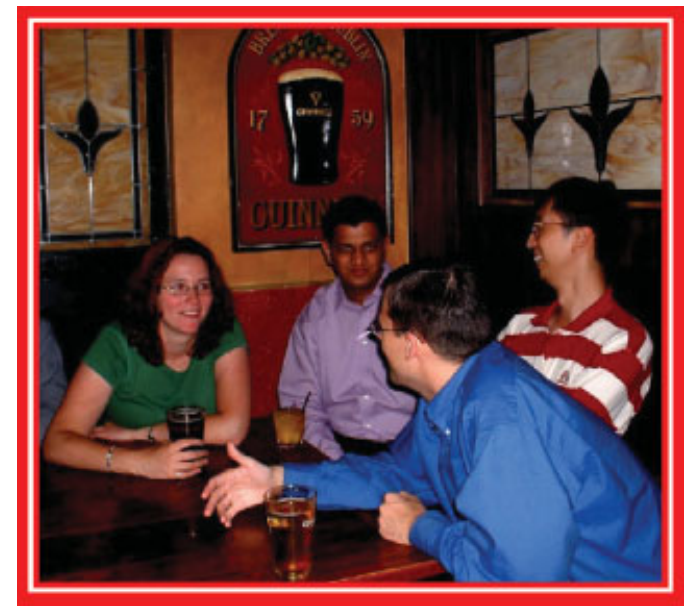

Fig. 1 Samantha Adams featured here with American Medical Informatics Association (AMIA) Student Working Group friends at MEDINFO 2004, San Francisco, featured in the AMIA Student Working Group Newsletter, September 2004, Vol. 1 (8). 


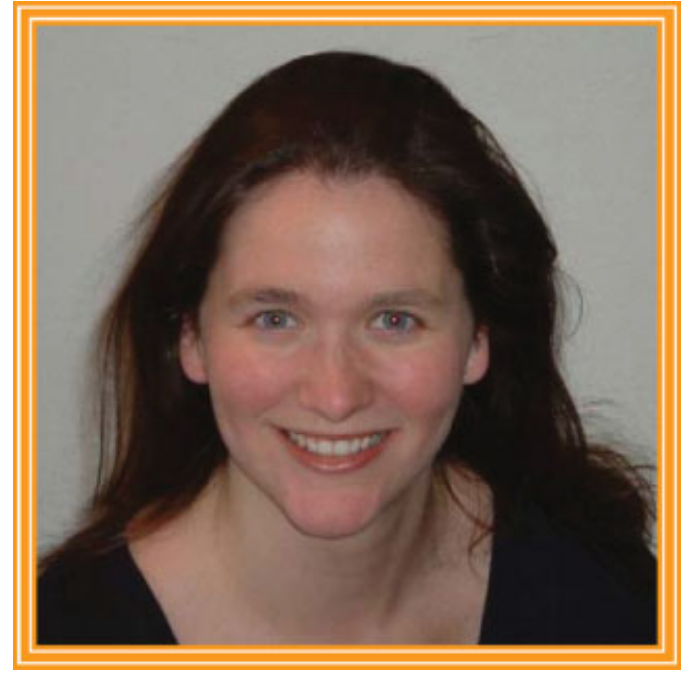

Fig. 2 Photo of Samantha Adams.

"I remember when I was about to conduct a very important interview at a Dutch public institution, and Sam, with a big smile, told me that the trick was 'to wear a blazer' and pretend it to be my 10th interview, not just one of the first," said Berti Suman. "I will always cherish the little and the big lessons I learned from Sam, and I will bring them forward, in her memory and in her legacy" (Email correspondence with Anna Berti Suman, February-March; 2018).
To close, here are a few more comments by these students: "I'm fortunate to have known her. I wish her family much love and strength." "I still find it very hard to get to terms with Sam's passing, let alone to write about her in a coherent manner." "I miss Sam as a person, and I miss her as a scholar. Everywhere I look, I come across her name: in my inbox, my text messages, my diary, my field notes. I can't believe I will never be able to talk with her again." "I miss her."

Yes, this is how we all feel. Thank you, and goodbye, Dr. Samantha Adams, dear Sam.

Samantha Adams featured here with AMIA Student Working Group friends at MEDINFO 2004, San Francisco, featured in the AMIA Student Working Group Newsletter, September 2004, Vol. 1 (8) (-Fig. 1).

A photo of Samantha Adams ( - Fig. 2) that accompanied her essay reporting on ITHC 2004: To Err is System, IT in Health Care: Socio-technical Approaches, Second International Conference, which took place 13-14, September 2004 in Portland, Oregon, USA, following MEDINFO 2004 in San Francisco. Sam's essay on ITHC appeared in the AMIA Student Working Group Newsletter, September 2004, Vol. 1 (8).

\section{References}

1 Adams S. "Reflection On ITHC 2004: To Err Is System. IT in Health Care: Sociotechnical Approaches." Craven CK, ed. The AMIA Student Working Group News 2004;1(08):5-6

2 Adams S. "Research Reactor." Craven CK, ed. The AMIA Student Working Group News 2004;1(09):3-4 